University of Nebraska - Lincoln

DigitalCommons@University of Nebraska - Lincoln

\title{
Spectroscopic Evidence for Uranium Bearing Precipitates in Vadose Zone Sediments at the Hanford 300-Area Site
}

Yuji Arai

Clemson University, yarai@clemson.edu

M. A. Marcus

Lawrence Berkeley National Laboratory

N. Tamura

Lawrence Berkeley National Laboratory

J. A. Davis

United States Geological Survey

John M. Zachara

Pacific Northwest National Laboratory, john.zachara@pnl.gov

Follow this and additional works at: https://digitalcommons.unl.edu/usdoepub

Part of the Bioresource and Agricultural Engineering Commons

Arai, Yuji; Marcus, M. A.; Tamura, N.; Davis, J. A.; and Zachara, John M., "Spectroscopic Evidence for Uranium Bearing Precipitates in Vadose Zone Sediments at the Hanford 300-Area Site" (2007). US Department of Energy Publications. 235.

https://digitalcommons.unl.edu/usdoepub/235

This Article is brought to you for free and open access by the U.S. Department of Energy at DigitalCommons@University of Nebraska - Lincoln. It has been accepted for inclusion in US Department of Energy Publications by an authorized administrator of DigitalCommons@University of Nebraska - Lincoln. 


\section{Spectroscopic Evidence for Uranium Bearing Precipitates in Vadose Zone Sediments at the Hanford 300-Area Site}

\author{
YUJI ARAI, ${ }^{*}$, M. A. MARCUS, ${ }^{\ddagger}$ \\ N. TAMURA, ${ }^{\ddagger}$ J.A. DAVIS, ${ }^{\S}$ AND \\ J. M. Z A C H A R A"
}

Department of Entomology, Soils, and Plant Sciences, 270 Poole Agricultural Center, Clemson University, Clemson, South Carolina 29634-0315, Lawrence Berkeley National Laboratory, Advanced Light Source, One Cyclotron Road, Berkeley, California 94720, United States Geological Survey, Water Resource Division, 345 Middlefield Road, MS 465, Menlo Park, California 94025, and Pacific Northwest Laboratory, Richland, Washington 99352

Uranium (U) solid-state speciation in vadose zone sediments collected beneath the former North Process Pond (NPP) in the 300 Area of the Hanford site (Washington) was investigated using multi-scale techniques. In 30 day batch experiments, only a small fraction of total $\mathrm{U}(\sim 7.4 \%)$ was released to artificial groundwater solutions equilibrated with $1 \% \mathrm{pCO}_{2}$. Synchrotron-based micro-X-ray fluorescence spectroscopy analyses showed that $U$ was distributed among at least two types of species: (i) $U$ discrete grains associated with $\mathrm{Cu}$ and (ii) areas with intermediate $\mathrm{U}$ concentrations on grains and grain coatings. Metatorbernite $\left(\mathrm{Cu}\left[\mathrm{UO}_{2}\right]_{2}\left[\mathrm{PO}_{4}\right]_{2} \cdot 8 \mathrm{H}_{2} \mathrm{O}\right)$ and uranophane $\left(\mathrm{Ca}\left[\mathrm{UO}_{2}\right]_{2}\left[\mathrm{SiO}_{3}(\mathrm{OH})\right]_{2} \cdot\right.$ $5 \mathrm{H}_{2} \mathrm{O}$ ) at some $\mathrm{U}$ discrete grains, and muscovite at $\mathrm{U}$ intermediate concentration areas, were identified in synchrotron-based micro-X-ray diffraction. Scanning electron microscopy/energy dispersive $\mathrm{X}$-ray analyses revealed 8-10 $\mu \mathrm{m}$ size metatorbernite particles that were embedded in $\mathrm{C}-, \mathrm{Al}-$, and Si-rich coatings on quartz and albite grains. In $\mu$ - and bulk-X-ray absorption structure ( $\mu$-XAS and XAS) spectroscopy analyses, the structure of metatorbernite with additional $\mathrm{U}-\mathrm{C}$ and $\mathrm{U}-\mathrm{U}$ coordination environments was consistently observed at $U$ discrete grains with high $U$ concentrations. The consistency of the $\mu$ - and bulk-XAS analyses suggests that metatorbernite may comprise a significant fraction of the total $U$ in the sample. The entrapped, micrometer-sized metatorbernite particles in C-, Al-, and Si-rich coatings, along with the more soluble precipitated uranyl carbonates and uranophane, likely control the long-term release of $\mathrm{U}$ to water associated with the vadose zone sediments.

\section{Introduction}

As a result of past nuclear fuel fabrication processes, uranium (U) has been recognized as one of the most widespread

\footnotetext{
* Corresponding author phone: (864)656-2607; fax: (864)656-3443; e-mail: yarai@clemson.edu.

${ }^{\dagger}$ Clemson University.

‡ Lawrence Berkeley National Laboratory.

$\S$ United States Geological Survey.

" Pacific Northwest Laboratory.
}

radionuclide contaminants in soils and groundwater at U.S. Department of Energy (DOE) sites, including the Hanford site in the state of Washington (U.S.). The 300 Area is one of many Hanford sites that received U-containing wastes during its mission of $\mathrm{Pu}$ production between 1940 and 1990 . Unirradiated fuel rod wastes were disposed to the 300 Area that included copper-uranium-nitric acid solutions and dissolved aluminum cladding (basic sodium aluminate). The DOE estimated that contaminants disposed in the North Process Pond (NPP) in the 300 Area included $\mathrm{Cu}$ (50 tons), nitrate (800 tons), nitric acid (900 tons), sodium aluminate (2000 tons), sodium hydroxide (800 tons), and enriched, natural, and depleted sources of U (30 tons) (1). Despite recent remediation efforts to remove the most contaminated top $(\sim 5 \mathrm{~m})$ sediments from this site, the environmental impact of residual $U(5-250 \mathrm{mg} / \mathrm{kg})$ in the vadose zone remains a major concern in protecting groundwater quality and controlling $U$ inputs to the adjacent Columbia River. In this critical zone, $U$ release is likely facilitated by variations in chemical/mineralogic speciation and $U$ concentration and site-specific physicochemical factors including (i) the mildly alkaline $\mathrm{pH}$ groundwater with $\mathrm{pCO}_{2}$ ranging from 0.1 to $1 \%$, (ii) infiltration of seasonal precipitation, and (iii) fluctuating groundwater table within the lower vadose zone (2). It is known that the predominant $U$ oxidation state is $U(V I)$ in these oxic/suboxic subsurface environments and that U(VI) speciation changes with depth (3). Uranium is released slowly from contaminated 300 Area sediments to percolating waters (4), and information is sought on the mechanisms responsible for the slow kinetics.

To accurately predict the $\mathrm{U}(\mathrm{VI})$ transport processes within the vadose zone, new conceptual models are needed that are consistent with molecular- to macro-scale experimental evidence. As part of a multi-scale investigation of the 300 Area site, the relationship between U solid-state speciation (e.g., sorbed and precipitated species) and reactivity in simulated groundwater solutions was investigated using a $U$ contaminated vadose zone sediment from the site. Spectroscopic studies, chemical digestion, batch experiments, and bulk mineralogical characterization were employed to elucidate possible mechanisms responsible for slow U(VI) release from the sediment. Specifically, detailed U solidstate speciation was investigated in this study using micro$\mathrm{X}$-ray absorption structure (XAS), micro-X-ray fluorescence spectroscopy ( $\mu$-XRF), scanning electron microscopy (SEM), and conventional bulk- and micro-X-ray diffraction (XRD).

\section{Materials and Methods}

Materials, Physicochemical Characterization, and Batch Experiments. A depth sequence of vadose zone sediments was collected beneath the former NPP site (NPP excavation \#2). Batch experiments were conducted in duplicate in a closed system with controlled $\mathrm{pCO}_{2}$ (i.e., air, and 0.1 and $1 \%$ $\mathrm{pCO}_{2}$ ). Physicochemical characterization and batch adsorption experiments were conducted according to details described in the Supporting Information (SI 1).

$\mu$-XRF, $\mu$-XAS, and Bulk-XAS Analyses. $\mu$-XRF and $\mu$-XAS analyses of sediments were performed at beamline (BL) 10.3.2 at the Advanced Light Source (ALS) (4). Uranium L LII-edge bulk-XAS measurements were conducted according to the method described by Arai and co-workers (5). A detailed description of the analytical procedures is described in SI 1.

$\mu$-XRD and SEM Analyses. To collect $\mu$-XRD patterns at $\mathrm{U}-\mathrm{Cu}$ hot spots (see the $\mu$-XRF Analyses) that were identified via $\mu$-XRF analysis at BL10.3.2, additional XRF compositional maps of $\mathrm{Cu}$ were generated under the monochromatic beam 
at BL 7.3.3, ALS (see SI 1 for experimental procedures). Geometric parameters such as sample to detector distance were accurately calibrated from diffraction patterns of quartz grains in the samples using the XMAS program (6). 2-D $\mu$-XRD patterns were converted into 1-D patterns by integration using the same software.

After the synchrotron-based spectroscopic analyses, the carbon coated thin section was used for further SEM analyses. A JEOL LEO982 Superprobe was operated at $15 \mathrm{kV}$ potential and a $30 \mathrm{nA}$ beam current. Electron voltages of 5-10 and 5-10 kV were used for backscatter electron imaging and energy dispersive X-ray analyses (EDS), respectively.

XAS Analyses. The bulk- and $\mu$-XAS data reduction and analysis were performed with the SiXPACK/IFEFFIT interface (7) using a method described previously (5). The program FEFF7.02 (8) was used to estimate backscattering phases and amplitude functions of single scattering (SS) $\left(\mathrm{U}-\mathrm{O}_{\mathrm{ax}}, \mathrm{U}-\mathrm{O}_{\mathrm{eq}}\right.$, $\mathrm{U}-\mathrm{C}, \mathrm{U}-\mathrm{P}, \mathrm{U}-\mathrm{U}$, and distal oxygen) and multiple scattering paths (MS) (transdioxo, $\mathrm{U}-\mathrm{O}_{\mathrm{eq}}-\mathrm{P}-\mathrm{U}$, and $\mathrm{U}-\mathrm{O}_{\mathrm{eq}}-\mathrm{P}-\mathrm{O}_{\mathrm{eq}}$ ), which were derived from structural refinement data of andersonite $\left(\mathrm{Na}_{2} \mathrm{CaUO}_{2}\left(\mathrm{CO}_{3}\right)_{3} \cdot 5.33 \mathrm{H}_{2} \mathrm{O}\right)$ (9), and metatorbernite $(10) . k^{3}$-Weighted Fourier transformed XAS spectra were fit in $R$-space over the range of $0-4.5 \AA$ with FEFF7.02 reference functions to estimate the local coordination environment of $U$ (i.e., coordination number $(\mathrm{CN})$, interatomic distances $(R)$, and the Debye-Waller factor $\left.\left(\sigma^{2}\right)\right)$. The $k^{3}$-weighted $\chi$ spectra were Fourier transformed to obtain radial structure functions at a $k$-range of $3-11.2 \AA^{-1}$. To facilitate comparison of different spectra, coordination numbers and $\sigma^{2}$ for some shells were fixed (i.e., $\mathrm{U}-\mathrm{C}, \mathrm{U}-\mathrm{O}_{\mathrm{eq}}-$ $\mathrm{P}-\mathrm{U}, \mathrm{U}-\mathrm{O}_{\mathrm{eq}}-\mathrm{P}-\mathrm{O}_{\text {eq }} \mathrm{MS}$, and $\mathrm{U}-\mathrm{U}$ ), and $R$ for all SS shells were allowed to vary. A single $E_{0}$ for all sets of backscattering atoms was used. Fixed values for $\mathrm{CN}$ and $R$ values for transdioxo uranium MS paths $\left(1: \mathrm{U}=\mathrm{O}_{\mathrm{ax}}=\mathrm{U}=\mathrm{O}_{\mathrm{ax} 2} ; 2\right.$ : $\mathrm{U}=$ $\mathrm{O}_{\mathrm{ax}}=\mathrm{O}_{\mathrm{ax} 2}$; and 3: $\mathrm{U}=\mathrm{O}_{\mathrm{ax}}=\mathrm{U}=\mathrm{O}_{\mathrm{ax}}$ ) were calculated based on the fit-derived values for axial shells (11). The other CN, $\sigma^{2}$, and $R$ values were allowed to vary unless otherwise mentioned in the text.

\section{Results and Discussion}

Chemical and Mineralogical Characterization of Sediments. Analyses of the HF digests (SI 2) showed the presence of $\mathrm{Al}$, $\mathrm{Fe}, \mathrm{Ca}, \mathrm{Ti}$, and $\mathrm{Mg}$ at typical crustal abundances $(\sim 7,8,4.6$, 1.2 , and $2 \%$ by weight, respectively) throughout the vertical profile of the NPP-2 excavation. Sodium was elevated ( $\sim 1.7 \%$ by wt) as a result of historic neutralization of acidic wastes with $\mathrm{NaOH}$. The total concentration of $U$ varied from 16 to $126 \mathrm{mg} / \mathrm{kg}$ between 0.61 and $3.66 \mathrm{~m}$ below ground surface (bgs). Another sample collected at $0.15 \mathrm{~m}$ that was not analyzed as part of this study contained the most $U$ in the sample series $(238 \mathrm{mg} / \mathrm{kg}$ ). High concentrations of $\mathrm{Cu}$ (up to $5200 \mathrm{mg} / \mathrm{kg}$ ) were observed in samples closer to the ground surface; these exhibited a greenish hue. Elevated concentrations of $\mathrm{P}$ were also observed throughout the profile. The source of $\mathrm{P}$ was phosphoric acid that was a minor cocontaminant in the acidic waste streams.

The sediments from the NPP-2 excavation were composed of granitic and basaltic lithic fragments $(\sim 90 \%)$ with lesser amounts of silt and clay. Calcite was present in the nearsurface sediments that were removed by excavation, but calcite was not found in these deeper vadose zone samples. There was little mineralogic difference observed between samples collected at different depths with powder X-ray diffraction. The lithic fragments contained a wide array of feldspars (albite, orthoclase, and plagioclase), pyroxenes, brushite, and hornblende; micas were also found (biotite and muscovite) $(12,13)$. The soil $\mathrm{pH}$ gradually increased from 7.18 to 7.53 with increasing depth bgs from 0.15 to $3.66 \mathrm{~m}$.

Batch Experiments. The results of the batch experiments are shown in SI 3. During the experiments, the $\mathrm{pH}$ of sediment solutions varied between 6.9 and $7.2,6.95-$ and 7.25 , and 7.18 - and 7.3 for the three $\mathrm{pCO}_{2}$ systems (i.e., air and 0.1 and $1 \% \mathrm{pCO}_{2}$, respectively). While we did not observe any significant trend in $\mathrm{Fe}$ or $\mathrm{Al}$ release as a function of $\mathrm{pCO}_{2}$, the release of $\mathrm{U}, \mathrm{P}$, and $\mathrm{Cu}$ was clearly affected by the concentration of bicarbonate in AGW solutions. U(VI) release increased with time and with increasing $\mathrm{pCO}_{2}$. The fraction of $\mathrm{U}(\mathrm{VI})$ released after 30 days to AGW equilibrated with $1 \%$ $\mathrm{pCO}_{2}$ was $\sim 7.4 \%$ of the total $U$, indicating that most of the sediment $U$ was resistant to rapid desorption or dissolution at pH 7.2. Enhanced P release could possibly be attributed to competitive bicarbonate adsorption on the aluminosilicate minerals or different rates of $\mathrm{P}$ dissolution from mineral phases such as brushite $\left(\mathrm{CaHPO}_{4} \cdot 2 \mathrm{H}_{2} \mathrm{O}\right)$. There was no trend of $\mathrm{Cu}$ release as a function of $\mathrm{pCO}_{2}$, but $\mathrm{Cu}$ concentrations in the AGW solutions were initially high and then decreased with time due to either $\mathrm{Cu}$ adsorption or $\mathrm{Cu}$ precipitation processes. While all systems were undersaturated with respect to $\mathrm{Cu}$ carbonates (azurite and malachite), schoepite, and any of $\mathrm{U}-\mathrm{Cu}$ species, they were slightly saturated with respect to crystalline tenorite, $\mathrm{CuO}$, during the initial 10 days (saturation index: $0.183-0.437$ ).

$\mu$-XRF Analyses. A bicolor $\mathrm{U}-\mathrm{Cu} \mu$-XRF map is shown in Figure la with $\mathrm{U}$ shown in red and $\mathrm{Cu}$ in green. It is important to note that elevated $U$ counts are magnified in Figure la, so that areas with intermediate to low U fluorescence counts do not appear. Spots containing both $\mathrm{Cu}$ and high $\mathrm{U}$ counts are in yellow or orange. From thereafter, these spots are referred to as $U$ discrete spots in the text. The $U$ discrete spots generally were moderate to high in $\mathrm{Cu}$ concentration in a monocolor $\mathrm{Cu} \mu$-XRF map (not shown), and as described next, the $\mathrm{Cu} \mu$-XRF map was used to locate the $\mathrm{U}$ discrete spots for $\mu$-XAS analyses. Such spots were randomly distributed throughout the entire map.

The $\mathrm{U}-\mathrm{Cu}$ elemental correlation was also observed in a scatter plot (SI 4a), where correlations appeared as rays. To locate areas containing $\mathrm{Cu}$ with intermediate $\mathrm{U}$ counts (see open red square in the $\mathrm{U}-\mathrm{Cu}$ scatterplot, SI 4a), the pixels corresponding to these $U$ fluorescence data points were translated onto a grayscale U XRF image (Figure $1 \mathrm{~b})$. The material containing both $\mathrm{Cu}$ and intermediate $\mathrm{U}$ counts is shown in gray. These areas exhibit $U$ coverage on grains (D-1-4) and coatings (D-5 and -6) (Figure 1b), and the areas represented were larger in spatial extent and lower in $U$ concentration than the $U$ discrete spots shown in Figure 1a. Pixels that were not within the red square of the $\mathrm{U}-\mathrm{C}$ scatterplot are shown in Figure $1 \mathrm{~b}$ in reddish-orange. Complete interpretation of the reddish-orange regions was confounded by fluorescence contributions of $\mathrm{Rb}$ as well as $\mathrm{U}$ and $\mathrm{Cu}$. However, it can be stated with certainty that the reddish-orange areas represented the pixels that are either low in $\mathrm{U}$ or $\mathrm{Cu}$ concentration or both. The $\mathrm{U}$ discrete spots in Figure la would not be included within the $\mathrm{U}-\mathrm{Cu}$ correlation ray (square in SI 4a) because of the high $U$ concentrations and, therefore, would also show up within the reddish-orange regions in Figure $1 b$.

At first glance, $\mathrm{U}$ was proportionally correlated with $\mathrm{Ca}$ (SI $4 \mathrm{~b}$ ), but this interpretation is incorrect due to an escape peak resulting in a similar Ca K $\alpha$ emission energy. The escape peak from $U$ pollutes the Ca counts with an extraneous signal proportional to the amount of $U$ at each pixel ( $U$ L $\alpha$ $(13.6 \mathrm{keV})-\mathrm{Ge} \mathrm{K} \alpha(9.9 \mathrm{keV})=3.7 \mathrm{keV}=\sim \mathrm{Ca} \mathrm{K} \alpha)$ ). This effect is illustrated in SI $4 \mathrm{~b}$, in which there is a branch representing pixels whose Ca counts come only from the U escape peak. This effect is dealt with by subtracting from each pixel's Ca count an amount proportional to the pixel's U counts, the constant of proportionality being chosen to make the Cafree areas appear Ca-free. The assumption that this branch represents material that is truly Ca-free was tested by looking at the energy spectrum below the U edge. Corrected $\mathrm{Ca} \mathrm{K \alpha}$ 

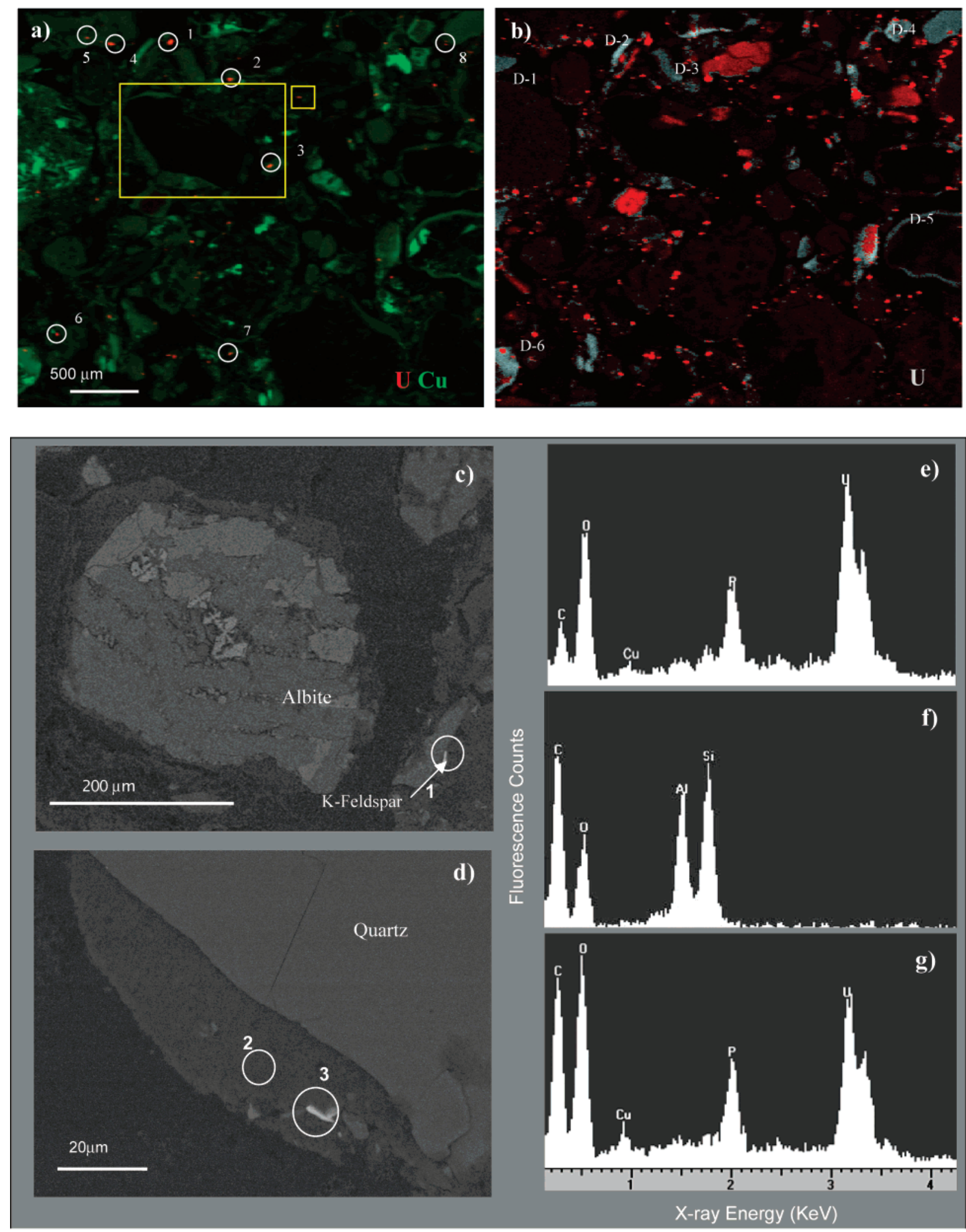

FIGURE 1. (a) Bicolor $U$ and Cu $\mu$-SXRF map of U contaminated Hanford vadose zone sediments (sample NPP2-4) (H: $3.5 \mathrm{~mm} \times \mathrm{V}: 3 \mathrm{~mm}$ ) ( $C u K \alpha$ in green and $U \mathrm{~L} \alpha$ in red). The intensity of each color pixel is proportional to the relative concentration of the corresponding element. Spots 1-8 indicate areas where $\mu$-XAS/-XRD spectra were taken. (b) Gray-scaled U $\mu$-XRF map, showing the same area as in panel a. Gray regions indicate areas of intermediate $U$ and Cu fluorescence counts. Red regions are explained in the text. (c and d) Backscatter SEM images taken at the large and small yellow squares in panel a, respectively. Bright areas (spots 1 and 3 ) indicate U-enriched grains. (e, $f$, and $g$ ) Energy dispersive spectra that were taken at spots 1-3 in panels $c$ and $d$, respectively.

signals (indicated by the green line in SI 4b) suggest no obvious correlation between $\mathrm{Ca}$ and $\mathrm{U}$. We found no obvious correlation in scatter plots with other uranium-metal $(\mathrm{Ni}$, $\mathrm{Cr}, \mathrm{Mn}, \mathrm{Fe}, \mathrm{Co}$, or $\mathrm{Zn})$ pairs (SI $4 \mathrm{c}-\mathrm{h})$. 
SEM Analyses. SEM/EDS analyses showed spatially resolved particle morphology and low Z element association at $U$ discrete spots (Figures $1 \mathrm{c}-\mathrm{g}$ ). SEM images (Figure 1c and 1d) were collected in the area represented by the two yellow squares (Figure 1a) of the same thin section that was used for $\mu$-XRF analyses. An elongated particle near a $\mathrm{K}$-feldspar grain contained $\mathrm{U}$ and $\mathrm{Cu}$, with $\mathrm{P}$ and $\mathrm{C}$ (Figure 1e). Another U-rich particle is embedded in the mixed $\mathrm{C}, \mathrm{Al}$, and Si coatings (Figure 1f,g) on the surface of a quartz grain. It is important to note that carbon signals from the samples were 20-30 times greater than that at resin-only areas, suggesting the U-rich particle association with carbon. The intensity of $\mathrm{C}$ in the second U-rich particle was greater than in the first particle (Figure 1e,g), indicating variations in the carbon abundance of the $U$ discrete particles. Although the result of total digestion indicated high levels of $\mathrm{Na}$ and $\mathrm{Ca}$ (SI 2) in the sediments, negligible $\mathrm{Na}$ or $\mathrm{Ca}$ was associated with either of the U-rich particles. Uranium association with $\mathrm{Cu}, \mathrm{P}$, and $\mathrm{C}$ was also consistently measured in three other particles (spots 1, 2, and 6, Figure la) that were located within mixed $\mathrm{C}, \mathrm{Al}$, and Si coatings on quartz, pyroxene, and albite grains (not shown).

$\mu$-XRD Analyses. Selected diffractograms of the $\mu$-XRD measurements are presented in Figure 2a (for spots 1 and 7 and area D-4). The $\mu$-XRD measurements were taken at most spots with observed high or intermediate U concentrations (spots $1-4$ and 6-8 in Figure $1 \mathrm{a}$ and D-1-4 and D-6 in Figure 1b). XRD patterns at spot 1 indicated the presence of metatorbernite, muscovite, and K-feldspar; metatorbernite was also found at spots 4, 5, 7, 8, and D-4. Uranophane, muscovite, and quartz were observed at spot 7 but not metatorbernite. Measurements at the locations of spots 2, 3, and 6 did not indicate the presence of metatorbernite; however, it is likely that this result arose from difficulties in locating the precise $\mathrm{U}$ discrete spots observed with $\mu$-XRF. Accurate registry of the $\mu$-XRD and $\mu$-XRF measurements was difficult because (i) the $\mathrm{Cu}$ fluorescence map was the only guide available for locating $\mathrm{Cu}$ associated U-rich spots because of the energy limitation $(<14 \mathrm{keV})$ at BL 7.3.3. and (ii) the shallow angle of the thin section with respect to the incident beam $\left(10^{\circ}\right)$ made the identification of specific particles difficult (i.e., the metatorbernite peak in area D-4 may actually arise from spot 8 , which is located very nearby). No metatorbernite peaks were observed in any of the other intermediate $U$ concentration areas (e.g., D-1-3), even though these areas also contained significant $\mathrm{Cu}$ concentrations. The absence of either metatorbernite or uranophane at these locations may indicate that $U$ is present as some other precipitated phase or as adsorbed U(VI). The observation of uranophane at spot 7 supports the $\mathrm{Ca}$ and $\mathrm{Si}$ correlation observed in U-rich areas in previous X-ray microprobe analyses (14). Muscovite was observed in every spectrum of $U$ discrete grains and in intermediate $U$ concentration areas. Calcite, not observed in bulk powder XRD measurements of the samples, was present in spot D- 4 .

$\mu$-XAS Analyses. To further elucidate U speciation, $\mu$-XAS spectra at spots $1-6$ and 8 and $\mu$-XANES spectra at intermediate $U$ concentration areas D1-D6 were analyzed. Because of the lower $U$ concentrations at spots D1-D6, the $\mu$-XAS analyses were limited to XANES. $\mu$-XANES analyses indicated that the $U$ valence state was predominantly U(VI). Although the $\mathrm{Si}(111)$ crystal that was used in the $\mu$-XANES measurements (Figure 2b) is not suited to distinguish U(VI) from U(IV), the shoulder features (indicated by arrows in Figure $2 \mathrm{~b}$ ) possibly indicate the presence of more reduced species. At these two spots (D4 and D6), a small fraction of $\mathrm{U}$ might be present as more reduced phases such as metallic U.

Figure 2c shows the $k^{3}$-weighted $\mathrm{U}_{\mathrm{III}}$-edge bulk- and $\mu$-EXAFS spectra (uncorrected for phase shift) for $U$ discrete grains, metatorbernite, and uranophane. Fit results are shown in Table 1 (in units of angstroms). Less than $1 \% R$-factor (i.e., the absolute misfit between calculations and data) in the EXAFS data indicated an excellent overall fit (Table 1). Interatomic distances mentioned in this section were corrected for phase shift unless otherwise mentioned in the text. The structural parameters of all samples contained two axial oxygen distances at approximately $1.8 \AA$ and equatorial oxygen distances at $\sim 2.3 \AA$. Additional shells were also observed U-C SS at $\sim 2.9 \AA$, corresponding to a carbonate ion coordination of the $U$ atom in a bidentate fashion (15), $\mathrm{U}-\mathrm{P}$ SS at $\sim 3.57 \AA$, and $\mathrm{U}-\mathrm{U}$ at $\sim 4.0$ and $4.48 \AA$. The interatomic distance of $\mathrm{U}-\mathrm{PSS}, \mathrm{U}-\mathrm{O}_{\mathrm{eq}}-\mathrm{P}-\mathrm{U}$, and $\mathrm{U}-\mathrm{O}_{\mathrm{eq}}-$ $\mathrm{P}-\mathrm{O}_{\text {eq }} \mathrm{MS}$ in metatorbernite were slightly different from the fit parameters previously reported by Catalano and Brown (16). A single $E_{0}$ was used for all sets of backscattering atoms in our fit, in contrast to the approach used by Catalano and Brown (16). The preliminary least-squares analyses were conducted on $\mu$-XAS spectra at spots $1-6$ and 8, first comparing with the spectrum for metatorbernite, which was observed by $\mu$-XRD at most spots. There were distinctive FT shells corresponding to U-P SS and MS paths in autunite groups (16) in all spectra (Figure 2d). These FT features at $3 \AA(R+\Delta R)$ are only observed in uranium phosphate minerals in the autunite group (e.g., ref 18), and the features are not present in other uranium-phosphate, -carbonate, and -silicate minerals (uranyl oxyhydroxides, carbonates, uranophane groups, or the meta-autunite group). Although $\mu$-XRD analyses indicated the presence of uranophane at spot 7 , the rest of the $\mu$-XAS spectra did not resemble the XAS spectrum of uranophane (Figure 2c,d). The fit results with the structural parameters of metatorbernite underestimated the experimental spectra (indicated by vertical dotted lines and an arrow in SI 5), inferring the presence of additional $\mathrm{U}(\mathrm{VI})$ coordination environments. This underestimate was also evident in the $k^{3}$-weighted EXAFS spectra in Figure 2c. The sample spectra were different from that of metatorbernite at $7-11 \AA^{-1}$.

To account for the unknown residual $U$ phases, additional $\mathrm{U}-\mathrm{C}$ SS with $\mathrm{U}-\mathrm{O}_{\text {dist }} \mathrm{SS} / \mathrm{MS}$ paths were included since different intensities of $\mathrm{C}$ signals were observed in $\mathrm{U}$ discrete grains in the SEM/EDS analyses (Figure 1e,g). The importance of the $\mathrm{U}-\mathrm{O}_{\text {dist }} \mathrm{SS}$ and MS contributions at $\sim 4.2 \AA$ has been reported in $U(V I)$-carbonate minerals (liebigite, čejkaite, rutherfordine, and zellerite) (16), as well as in the triscarbonato aqueous species (17) and U(VI)-carbonato ternary surface species at mineral-water interfaces $(5,18)$. Other than the distal oxygen contribution of bicarbonate ligand(s), there are only a few other possibilities that can explain the FT features at $>3.9 \AA(R+\Delta R)$. In carbon and phosphorus associated $\mathrm{U}$ minerals, $\mathrm{U}-\mathrm{U}$ distances have been often documented in uranyl orthophosphate $\left(\left(\mathrm{UO}_{2}\right)_{3}\left(\mathrm{PO}_{4}\right)_{2} \cdot 4 \mathrm{H}_{2} \mathrm{O}\right)$ and rutherfordine $\left(\mathrm{UO}_{2} \mathrm{CO}_{3}\right)$ ) (e.g., ref 18) at these long distances. $\mathrm{U}-\mathrm{U}$ scattering at these distances has not been observed in the autunite group.

When $\mathrm{U}-\mathrm{C}$ and $\mathrm{U}-\mathrm{U}$ SS paths were included, the fit significantly improved, as shown in Table 1 and Figures 2c and $2 \mathrm{~d}$. Different degrees of $\mathrm{C}$ incorporation in the $\mathrm{U}$ discrete grains as observed in EDS analyses were supported by coordination numbers of $\mathrm{U}-\mathrm{C}(\sim 1$ to $\sim 3 \pm 2)$ that varied among the spots (Table 1). Inclusion of the $\mathrm{U}-\mathrm{O}_{\text {dist }} \mathrm{SS}$ and MS was not necessary in most of the spectra, except for the spectrum at spot 3 . $\mathrm{CN}$ and $\mathrm{R}$ of $\mathrm{U}-\mathrm{O}_{\text {dist }} \mathrm{SS} / \mathrm{MS}$ at spot 3 were $\sim 2.4$ and $\sim 4.18 \AA$, respectively. In addition to these distal oxygen SS and MS distances, $\mathrm{U}-\mathrm{U}$ distances at spot $3(\sim 4.5 \AA)$ exhibited an intermediate $\mathrm{U}-\mathrm{U}$ distance that was observed in the XAS analysis of rutherfordine $\left(\mathrm{UO}_{2} \mathrm{CO}_{3}\right)(16)$. These $\mathrm{U}-\mathrm{O}_{\text {dist }}$ and $\mathrm{U}-\mathrm{U}$ distances were consistent with the structural parameters of rutherfordine reported by other researchers $(16,19)$, suggesting that spot 3 might contain 

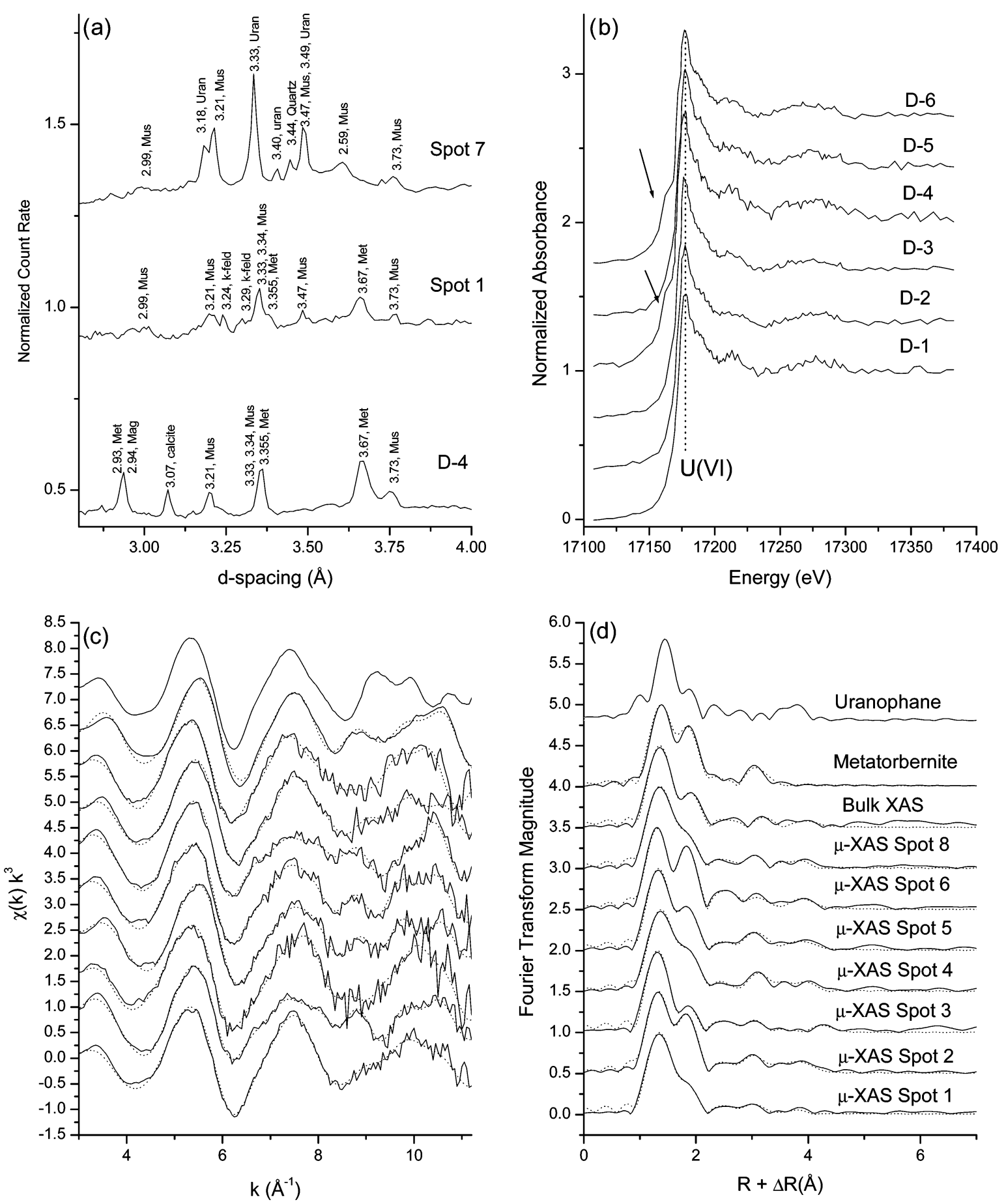

FIGURE 2. (a) Microfocused XRD patterns of spots 1 and 7 in Figure 1a and area D-4 in Figure 1b. Mus: muscovite, Met: metatorbernite, K-feld: K-feldspar, Uran: uranophane, Cal: calcite, 0 tz: quartz, and Mag: magnetite. (b) U L LII-edge $\mu$-XANES spectra taken at areas with intermediate $U$ and $C u$ concentrations (D-1-6) in Figure $1 \mathrm{~b}$. Nonlinear least-squares fits to normalized $\boldsymbol{k}^{3}$-weighted $\mu$-and bulk-EXAFS spectra of vadose zone sediments, uranophane and metatorbernite in panel $\mathrm{c}$ and nonlinear least-squares fits to Fourier transforms in panel d. Raw data and fits are shown by solid and dotted lines, respectively. See Table 1 for fit parameters.

amorphous rutherfordine in addition to crystalline metatorbernite. Although a few $\mu$-XANES data (Figure 2b, D-4 and D-6) might indicate the presence of metallic $U$ in the sample, $\mathrm{U}-\mathrm{U}$ distances at 2.9 and $\sim 3.3$ A that were observed in the FEFF/XRD simulation of $\alpha$-metallic U (20) were not successfully included in the EXAFS analyses. Unlike spot 3 , most of the other spots had $\mathrm{U}-\mathrm{U}$ distances of $\sim 4 \AA$. This distance is slightly longer than the $\mathrm{U}-\mathrm{U}$ distance of a dimer ( $3.8 \AA)(21)$ and metallic U, and therefore, we suggest that the $\mathrm{U}-\mathrm{U}$ signals were derived from disordered uranyl carbonate precipitates (but not calcium uranyl carbonate minerals such as liebigite and čejkaite) that were associated with the metatorbernite particles in the C-, Al-, and Si-rich coatings of the sediment grains. $\mathrm{U} / \mathrm{Cu}$ ratios in the EDS spectra (Figure 1e,g) were too high to result only from metatorbernite. The uranium-carbonate precipitates may have contributed to the additional U signal.

Although U substituted calcite has been observed in waste pond sediments collected from this site (22), we did not consider $\mathrm{U}$ substituted calcite in the $\mu$-XAS interpretation because SEM/EDS and $\mu$-XRD analyses showed no Ca within or near the $U$ discrete grains (Figures 1e,g and 2a). Calcite was, however, observed at one intermediate $U$ spot (D-4, Figure 2a). 


\begin{tabular}{|c|c|c|c|c|c|c|c|c|c|}
\hline samples & & $\mathbf{0}_{\mathrm{ax}}$ & $\mathbf{0}_{\mathrm{eq}}$ & C & $\mathbf{P}$ & MS1 & MS2 & U & $R$-factor \\
\hline$\mu$-XAS at spot 1 & $\begin{array}{l}\mathrm{CN} \\
R(\AA) \\
\sigma^{2}\left(\AA^{2}\right)\end{array}$ & $\begin{array}{l}2.3(5) \\
1.77(2) \\
0.0027(2)\end{array}$ & $\begin{array}{l}6(1) \\
2.27(1) \\
0.007(3)\end{array}$ & $\begin{array}{l}1.6(9) \\
2.95(4) \\
0.004^{b}\end{array}$ & $\begin{array}{l}4^{b} \\
3.55(9) \\
0.007(2)\end{array}$ & $\begin{array}{l}8^{b} \\
3.7(2) \\
0.004^{b}\end{array}$ & $\begin{array}{l}4^{b} \\
3.77(5) \\
0.004^{b}\end{array}$ & $\begin{array}{l}2(1) \\
4(1) \\
0.007^{b}\end{array}$ & 0.0033 \\
\hline$\mu$-XAS at spot 2 & $\begin{array}{l}C N \\
R(\AA) \\
\sigma^{2}\left(\AA^{2}\right)\end{array}$ & $\begin{array}{l}2.5(5) \\
1.75(1) \\
0.006(1)\end{array}$ & $\begin{array}{l}6(1) \\
2.31(1) \\
0.007\end{array}$ & $\begin{array}{l}1.8(8) \\
2.95(3) \\
0.004^{b}\end{array}$ & $\begin{array}{l}4^{b} \\
3.57(2)\end{array}$ & $\begin{array}{l}8^{b} \\
3.75(9) \\
0.004^{b}\end{array}$ & $\begin{array}{l}4^{b} \\
3.84(8) \\
0.004^{b}\end{array}$ & $\begin{array}{l}2.4(9) \\
4.00(3) \\
0.007 b\end{array}$ & 0.0043 \\
\hline$\mu$-XAS at spot 3 & $\begin{array}{l}C N \\
R(\AA) \\
\sigma^{2}\left(\AA^{2}\right)\end{array}$ & $\begin{array}{l}2.3(4) \\
1.803(4) \\
0.0011(3)\end{array}$ & $\begin{array}{l}5(2) \\
2.27(2) \\
0.007(3)\end{array}$ & $\begin{array}{l}3(2) \\
2.91(3) \\
0.004^{b}\end{array}$ & $\begin{array}{l}4^{b} \\
3.57(3) \\
0.005(2)\end{array}$ & $\begin{array}{l}8^{b} \\
3.75(9) \\
0.004^{b}\end{array}$ & $\begin{array}{l}4^{b} \\
3.84(8) \\
0.004^{b}\end{array}$ & $\begin{array}{l}3(2) \\
4.48(4) \\
0.007^{b}\end{array}$ & 0.0029 \\
\hline$\mu$-XAS at spot 4 & $\begin{array}{l}C N \\
R(\AA) \\
\sigma^{2}\left(\AA^{2}\right)\end{array}$ & $\begin{array}{l}2.3(5) \\
1.77(1) \\
0.005(2)\end{array}$ & $\begin{array}{l}5(1) \\
2.29(2) \\
0.009(3)\end{array}$ & $\begin{array}{l}2(1) \\
2.88(6) \\
0.004^{b}\end{array}$ & $\begin{array}{l}4^{b} \\
3.6(1) \\
0.006(3)\end{array}$ & $\begin{array}{l}8^{b} \\
3.7(3) \\
0.004^{b}\end{array}$ & $\begin{array}{l}4^{b} \\
3.8(2) \\
0.004^{b}\end{array}$ & $\begin{array}{l}2(1) \\
4.0(1) \\
0.007^{b}\end{array}$ & 0.0051 \\
\hline$\mu$-XAS at spot 5 & $\begin{array}{l}C N \\
R(\AA) \\
\sigma^{2}\left(\AA^{2}\right)\end{array}$ & $\begin{array}{l}2.3(5) \\
1.76(1) \\
0.003(2)\end{array}$ & $\begin{array}{l}5(1) \\
2.30(2) \\
0.007(3)\end{array}$ & $\begin{array}{l}1.4(1) \\
2.91(6) \\
0.004^{b}\end{array}$ & $\begin{array}{l}4^{b} \\
3.58(7) \\
0.003(3)\end{array}$ & $\begin{array}{l}8^{b} \\
3.7(3) \\
0.004^{b}\end{array}$ & $\begin{array}{l}4^{b} \\
3.8(1) \\
0.004^{b}\end{array}$ & $\begin{array}{l}2(1) \\
4.0(1) \\
0.007^{b}\end{array}$ & 0.0043 \\
\hline$\mu$-XAS at spot 6 & $\begin{array}{l}C N \\
R(\AA) \\
\sigma^{2}\left(\AA^{2}\right)\end{array}$ & $\begin{array}{l}2.2(6) \\
1.74(1) \\
0.004(2)\end{array}$ & $\begin{array}{l}6(1) \\
2.31(1) \\
0.007(2)\end{array}$ & $\begin{array}{l}3(1) \\
2.94(2) \\
0.004^{b}\end{array}$ & $\begin{array}{l}4^{b} \\
3.5(2) \\
0.01(1)\end{array}$ & $\begin{array}{l}8^{b} \\
3.6(2) \\
0.004^{b}\end{array}$ & $\begin{array}{l}4^{b} \\
3.79(5) \\
0.004^{b}\end{array}$ & $\begin{array}{l}3(1) \\
4.02(3) \\
0.007^{b}\end{array}$ & 0.0069 \\
\hline$\mu$-XAS at spot 8 & $\begin{array}{l}C N \\
R(\AA) \\
\sigma^{2}\left(\AA^{2}\right)\end{array}$ & $\begin{array}{l}2.4(3) \\
1.77(1) \\
0.005(1)\end{array}$ & $\begin{array}{l}4.5(5) \\
2.28(2) \\
0.009(3)\end{array}$ & $\begin{array}{l}2(1) \\
2.88(5) \\
0.004^{b}\end{array}$ & $\begin{array}{l}4^{b} \\
3.6(1) \\
0.006(3)\end{array}$ & $\begin{array}{l}8^{b} \\
3.7(3) \\
0.004^{b}\end{array}$ & $\begin{array}{l}4^{b} \\
3.8(4) \\
0.004^{b}\end{array}$ & $\begin{array}{l}2(1) \\
3.97(5) \\
0.007^{b}\end{array}$ & 0.004 \\
\hline bulk-XAS & $\begin{array}{l}C N \\
R(\AA) \\
\sigma^{2}\left(\AA^{2}\right)\end{array}$ & $\begin{array}{l}2.3(5) \\
1.78(2) \\
0.002(2)\end{array}$ & $\begin{array}{l}5(2) \\
2.32(5) \\
0.008(5)\end{array}$ & $\begin{array}{l}1(1) \\
2.93(8) \\
0.004^{b}\end{array}$ & $\begin{array}{l}4^{b} \\
3.6(1) \\
0.01(1)\end{array}$ & $\begin{array}{l}8^{b} \\
3.7(1) \\
0.004^{b}\end{array}$ & $\begin{array}{l}4^{b} \\
3.8(1) \\
0.004^{b}\end{array}$ & $\begin{array}{l}2(1) \\
4.0(3) \\
0.007^{b}\end{array}$ & 0.0068 \\
\hline metatorbernite & $\begin{array}{l}C N \\
R(\AA) \\
\sigma^{2}\left(\AA^{2}\right)\end{array}$ & $\begin{array}{l}2^{b} \\
1.774(7) \\
0.0025(5)\end{array}$ & $\begin{array}{l}4^{b} \\
2.291(9) \\
0.0038(6)\end{array}$ & & $\begin{array}{l}4^{b} \\
3.59(4) \\
0.005(1)\end{array}$ & $\begin{array}{l}8^{b} \\
3.74(9) \\
0.004^{b}\end{array}$ & $\begin{array}{l}4^{b} \\
3.85(7) \\
0.004^{b}\end{array}$ & & 0.0016 \\
\hline
\end{tabular}

${ }^{a} \mathrm{CN}$ : coordination number. $R$ : interatomic distance $(\AA)$. $\sigma^{2}$ : Debye-Waller factor $\left(\AA^{2}\right)$. Fit quality confidence limit for parameters: $U-\mathrm{O}_{\text {ax }}: \pm 15 \%$ and $\pm 0.02 \AA ; U-\mathrm{O}_{\text {eq }}: \pm 20 \%$ and $\pm 0.02 \AA$; and $\mathrm{U}-\mathrm{P} / \mathrm{U}: \pm 25 \%$ and $\pm 0.02 \AA .{ }^{b}$ Fixed parameters. Parameters for three $\mathrm{U}=\mathrm{O}_{\mathrm{ax}} \mathrm{MS}$ paths $\left(R\right.$ : $2 R_{\mathrm{Oax}}$ $\AA$ and $\sigma^{2}: 2 \sigma^{2}$ oax $)$ are omitted from the table. MS1 and MS2 indicate multiple scattering paths along $\mathrm{U}-\mathrm{O}_{\text {eq }}-\mathrm{P}-\mathrm{U}$ and $\mathrm{U}-\mathrm{O}$ eq $-\mathrm{P}-\mathrm{O}_{\mathrm{eq}}-\mathrm{U}$, respectively. Parameters of $\mathrm{U}-\mathrm{O}_{\text {dist }} \mathrm{SS}$ and two $\mathrm{U}-\mathrm{C}-\mathrm{O}_{\text {dis }} \mathrm{MS}$ paths at spot 3 are $\mathrm{CN}: 2.4 ; R: 4.17(7)$; and $\sigma^{2}: 0.004^{*}$ and $\mathrm{CN}: 2.4 ; R$ : 4.19 ; and $\sigma^{2}$ : $0.004 *$, respectively.

As the SEM/EDS analyses indicated, the $U$ discrete grains were consistently cemented within $\mathrm{C}-$, $\mathrm{Al}-$, and Si-rich coatings on quartz and albite grains. Under the highly varied chemical conditions that existed during the history of the pond operations (e.g., intermittent disposal of acidic copperuranium - nitric acid and basic sodium aluminate solutions), it appears that dissolution and precipitation events occurred within the vadose zone that trapped metatorbernite and disordered uranyl carbonate precipitates within aluminosilicate grain coatings.

Bulk-XAS Analyses. Considering the similar millimeterscale analyses between $\mu$-XRF mapping (Figure 1a) and bulkXAS measurements, it is reasonable to assume that a significant portion of the $U$ fluorescence counts originated from U-rich spots that represent cemented metatorbernite particles and uranium-carbonate precipitates in grain coatings. Prior to constraining the fitting parameters of the bulk-XAS analyses with the results of $\mu$-XAS analyses, however, we have also considered adsorbed U(VI) species on aluminosilicate minerals, as amorphous aluminosilicates may be an important component of the thick coatings observed on larger grains (Figures $1 \mathrm{c}$ and $1 \mathrm{~d}$ ), and adsorbed $\mathrm{U}(\mathrm{VI})$ species could be significant in bulk-scale analyses. Catalano and Brown recently reported that $\mathrm{U}(\mathrm{VI})$ adsorption to Fe-containing smectite occurred primarily on octahedral iron sites exposed on phyllosilicate edges (14). U-Fe distances of $\sim 3.45 \AA$, which are also commonly observed in U(VI)reacted iron oxyhydroxides (e.g., refs 15 and 23) were observed. In initial fitting, we included $\mathrm{U}-\mathrm{Al}(\sim 3.3 \AA)$ and $\mathrm{U}-$ Fe distances $(\sim 3.42 \AA)(5,15,24)$ to account for possible adsorbed U(VI) species on iron oxyhydroxide, aluminosilicate, and Fe-containing phyllosilicates that are known to exist in these sediments. However, a reasonable fit could not be obtained with any of these adsorbed species. Difficulties in isolating the $\mathrm{U}$ L $\alpha$ signal (13 614.7 eV) from a $\mathrm{Rb} \mathrm{K} \alpha$ background signal (13 $395.3 \mathrm{eV}$ ) may cause an insufficient signal-to-noise ratio to allow the discrimination of adsorbed species that are a small fraction of the total U pool.
On the basis of the previous reports of high calcite content (>3 wt \%) in the pond bottom sediments (3), U incorporation within calcite was also considered in the bulk-XAS analyses. Although a corrected $\mathrm{U}-\mathrm{Ca}$ correlation plot (the green line in SI 1b) indicated no obvious correlation between these elements, low $U$ fluorescence signals might be contributed from calcite, which contains a trace amount of U. Important $\mathrm{U}-\mathrm{C}$ and $\mathrm{U}-\mathrm{Ca}$ interatomic distances that have been reported for synthetic/natural $U$ incorporated calcite were considered (25-28). We excluded the formation of tetravalent $\mathrm{U}$ in calcite because the transdioxo structure was identified in XAS analyses. Our U-C distance of $\sim 2.9 \AA$ is significantly shorter than the monodentate coordination distance ( $\sim 3.5 \AA$ ) reported by Kelly et al. (27), but it is reasonably close to the distance $(\sim 2.92 \AA)$ reported by Reeder et al. (25, 26). However, U-Ca distances at 3.78-4.01 $\AA(25,26)$ could not be included in the fit. Overall, the bulk-XAS spectrum was successfully fit (Figure 2d) with similar structural parameters observed in the $\mu$-XAS spectra.

Implications for Predicting $U$ Release in Vadose Zone Sediments at the Hanford $\mathbf{3 0 0}$ Area. The 300 A U(VI) groundwater plume has persisted to this day in spite of excavation and removal of the upper $5 \mathrm{~m}$ of more highly contaminated sediments (some in excess of $2000 \mathrm{mg} / \mathrm{kg}$ ) from the former waste ponds including the NPP studied here $(3,29)$ and copious flux of carbonate-containing groundwater through the contaminated aquifer region. The persistence of the high groundwater $\mathrm{U}(\mathrm{VI})$ concentrations is believed to result from (i) the re-supply of contaminant $U$ from the vadose zone and capillary fringe, (ii) slow desorption/dissolution rates in the vadose and saturated zones, and (iii) seasonal infiltration events of Columbia River water that encourage $\mathrm{U}(\mathrm{VI})$ readsorption to aquifer solids.

In this study, we investigated $U$ chemical speciation in a single U-enriched vadose zone sediment collected from $1.2 \mathrm{~m}$ beneath the remediated source term region. The predominant $U$ species were found to be metatorbernite with associated uranyl-carbonate precipitates that were embed- 
ded in grain coatings resulting from past waste discharges and resulting sediment-waste reactions. Metatorbernite is an unusual U-containing mineral phase that is infrequently observed in the field and has never been reported at a nuclear weapons legacy site. We demonstrate that the application of $\mathrm{X}$-ray microprobes provides critical and necessary constraints in the development of a scientifically credible macroscopic speciation model for this complex contaminated natural sediment.

Slow, mass transfer limited dissolution of the precipitated uranyl carbonates and metatorbernite embedded within grain coatings in this and other like contaminated sediments in the upper vadose zone may be an important long-term source of $U(V I)$ to infiltrating meteoric waters. In this particular case, $\mathrm{U}(\mathrm{VI})$ dissolution rate and extent may be regulated by the solubility of closely associated $\mathrm{Cu}$ phases (e.g., $\mathrm{CuO}$ ) that greatly exceed $\mathrm{U}$ in concentration, as $\mathrm{U}(\mathrm{VI})$ exists in $\mathrm{Cu}-$ containing precipitates and coatings. Uranium-enriched pore waters resulting from the dissolution of these precipitates may equilibrate with underlying sediments through surface complexation and other reaction types, eventually breaking through to groundwater.

Although we have not reported on the $U$ chemical speciation in samples collected closer to the original pit surface, preliminary measurements suggest that the spatial distribution and phase identity of $U$ within them is significantly different from the sample collected at $1.2 \mathrm{~m}$ bgs that was studied here, with no evidence of micrometer-sized metatorbernite particles. Thus, $U$ speciation is highly variable as a function of depth within the vadose zone sediments. Depth-specific $U$ chemical speciation is critical for the development of an accurate conceptual geochemical model for the vadose zone to drive scientifically credible reactive transport calculations of future vadose zone fluxes of $U$ to groundwater.

\section{Supporting Information Available}

Physiochemical characterization of sediments; batch experiments; $\mu$-XRF, -XAS, and -XRD analytical procedures; XRF scatterplots; EXAFS spectra; and acknowledgments (SI 1-5). This material is available free of charge via the Internet at http://pubs.acs.org.

\section{Literature Cited}

(1) Wang, Z.; Zachara, J. M.; Yantasee, W.; Gassman, P. L.; Liu, C.; Joly, A. G. Cryogenic laser induced fluorescence characterization of U(VI) in Hanford vadose zone pore waters. Environ. Sci. Technol. 2004, 38, 5591-5597.

(2) Waichler, S. R.; Yabusaki, S. B. Flow and Transport in the Hanford 300 Area Vadose Zone-Aquifer-River System; PNNL-15125; Pacific Northwest National Laboratory: Richland, WA, 2005.

(3) Catalano, J. G.; McKinley, J. P.; Zachara, J. M.; Heald, S. M.; Smith, S. C.; Brown, G. E., Jr. Changes in uranium speciation through a depth sequence of contaminated Hanford sediments. Environ. Sci. Technol. 2006, 40, 2517-2524.

(4) Marcus, M. A.; MacDowell, A. A.; Celestre, R.; Manceau, A.; Miller, T.; Padmore, H. A.; Sublett, R. E. Beamline 10.3.2 at ALS: A hard $\mathrm{X}$-ray microprobe for environmental and materials sciences. J. Synchrotron Radiat. 2004, 11, 239-247.

(5) Arai, Y.; McBeath, M.; Bargar, J. R.; Joye, J.; Davis, J. A. Uranyl adsorption and surface speciation at the imogolite-water interface: Self-consistent spectroscopic and surface complexation models. Geochim. Cosmochim. Acta 2006, 70 (10), 24922509.

(6) Tamura, N.; Spolenak, R.; Valek, B. C.; Manceau, A.; Chang, M. M.; Celestre, R. S.; MacDowell, A. A.; Padmore, H. A.; Patel, J. R. Submicrometer X-Ray diffraction and its applications to problems in materials and environmental science. Rev. Sci. Instrum. 2002, 73, 1369-1372.

(7) Webb, S. M. A graphical user interface for XAS analysis using IFEFFIT. Phys. Scripta 2005, 115, 1011-1014.

(8) Rehr, J. J.; Albers, R. C.; Zabinsky, S. I. High-order multiple scattering calculations of X-ray absorption fine structure. Phys. Rev. Lett. 1992, 69, 3379-3400.
(9) Mereiter, K. Neue kristallographische daten ueber das uranmineral andersonit. Anz. Oesterr. Akad. Wiss., Math.-Naturwiss. Kl. 1986, 123 (3), 39-41.

(10) Ross, M.; Evans, H. T.; Appleman, D. E.; Studies of torbernite minerals. 2. Crystal structure of meta-torbernite. Am. Mineral. 1964, 49, 1603-1621.

(11) Hudson, E. A.; Allen, P. G.; Terminello, L. J.; Denecke, M. A.; Reich, T. Polarized X-ray absorption spectroscopy of the uranyl ion: Comparison of experiment and theory. Phys. Rev. B 1996, $54,156-165$.

(12) Qafoku, N. P.; Zachara, J. M.; Liu, C.; Gassman, P. L.; Qafoku, O. S.; Smith, S. C. Kinetic desorption and sorption of U(VI) during reactive transport in a contaminated Hanford sediment. Environ. Sci. Technol. 2005, 39, 3157-3165.

(13) Serne, R. J.; Brown, C. F.; Schaef, H. T.; Pierce, E. M.; Lindberg, M. J.; Wang, Z.; Gassman, P. L.; Catalano, J. G. 300 Area Uranium Leach and Adsorption Project; PNNL-14022; Pacific Northwest National Laboratory: Richland, WA, 2002.

(14) Catalano, J. G.; Brown, G. E. J. Uranyl adsorption onto montmorillonite: Evaluation of binding sites and carbonate complexation. Geochim. Cosmochim. Acta 2005, 69 (12), 2995-3005.

(15) Bargar, J. R.; Reitmeyer, R.; Lenhart, J. J.; Davis, J. A. Characterization of U(VI)-carbonato ternary complexes on hematite: EXAFS and electrophoretic mobility measurements. Geochim. Cosmochim. Acta 2000, 64 (16), 2737-2749.

(16) Catalano, J. G.; Brown, G. E. J. Analysis of uranyl bearing phases by EXAFS spectroscopy: Interferences, multiple scattering, accuracy of structural parameters, and spectral differences. Am. Mineral. 2004, 89, 1004-1021.

(17) Bernhard, G.; Geipel, G.; Reich, T.; Amayri, S.; Nitsche, H. Uranyl(VI) carbonate complex formation: Validation of the $\mathrm{Ca}_{2} \mathrm{UO}_{2-}$ $\left(\mathrm{CO}_{3}\right)_{3}(\mathrm{aq})$ species. Radiochim. Acta 2001, 89, 511-518.

(18) Elzinga, E. J.; Tait, C. D.; Reeder, R. J.; Rector, K. D.; Donohoe R. T.; Morris, D. E. Spectroscopic investigation of U(VI) sorption at the calcite-water interface. Geochim. Cosmochim. Acta 2004 68 (11), 2437-2448.

(19) Thompson, H. A.; Brown, G. E. J.; Parks, G. A. XAFS spectroscopic study of uranyl coordination in solids and aqueous solution. Am. Mineral. 1997, 82, 483-496.

(20) Wyckoff, R. W. G. Crystal Stuctures, 2nd ed.; Interscience Publisher: New York, 1964; Vol. 2.

(21) Duff, M. C.; Hunter, D. B.; Hobbs, D. T.; Fink, S. D.; Dai, Z.; Bradley, J. P. Mechanisms of strontium and uranium removal from high-level radioactive waste simulant solutions by the sorbent monosodium titanate. Environ. Sci. Technol. 2004, 38, 5201-5207.

(22) Wang, Z.; Zachara, J. M.; McKinley, J. P.; Smith, S. C. Cryogenic laser induced U(VI) fluorescence studies of a U(VI) substituted natural calcite: Implications to U(VI) speciation in contaminated Hanford sediments. Environ. Sci. Technol. 2005, 39, 2651-2659.

(23) Waite, T. D.; Davis, J. A.; Payne, T. E.; Waychunas, G. A.; Xu, N. Uranium(VI) adsorption to ferrihydrite: Application of a surface complexation model. Geochim. Cosmochim. Acta 1994, 58 (24), 5465-5478.

(24) Hennig, C.; Reich, T.; Dähn, R.; Scheidegger, A. M. Structure of uranium sorption complexes at montmorillonite edge sites. Radiochim. Acta 2002, 90, 653-657.

(25) Reeder, R. J.; Nugent, M.; Lamble, G. M.; Tait, C. D.; Morris, D. E. Uranyl incorporation into calcite and aragonite: XAFS and luminescence studies. Environ. Sci. Technol. 2000, 34, 638-644.

(26) Reeder, R. J.; Nugent, M.; Tait, C. D.; Morris, D. E.; Heald, S. M.; Beck, K. M.; Hess, W. P.; Lanzirotti, A. Coprecipitation of uranium(VI) with calcite: XAFS, micro-XAS, and luminescence characterization. Geochim. Cosmochim. Acta 2001, 65 (20), 3491-3503.

(27) Kelly, S. D.; Newville, M. G.; Cheng, L.; Kemner, K. M.; Sutton, S. R.; Fenter, P.; Sturchio, N. C.; Spötl, C. Uranyl incorporation in natural calcite. Environ. Sci. Technol. 2003, 37, 1284-1287.

(28) Sturchio, N. C.; Antonio, M. R.; Soderholm, L.; Sutton, S. R.; Brannon, J. C. Tetravalent uranium in calcite. Science 2004, 281, 971-972.

(29) Zachara, J. M.; Davis, J. A.; Liu, C.; McKinley, J. P.; Qafoku, N. P.; Wellman, D. M.; Yabusaki, S. B. Uranium Geochemistry in Vadose Zone and Aquifer Sediments from the 300 Area Uranium Plume; PNNL-15121; Pacific Northwest National Laboratory: Richland, WA, 2005.

Received for review September 13, 2006. Revised manuscript received April 3, 2007. Accepted April 11, 2007.

\section{ES062196U}

